\title{
Study of Potential Pollution of Sasirangan Liquid Waste with Biological and Chemical Parameters
}

\author{
Isna Syauqiah ${ }^{1,2}$, Desi Nurandini $^{1^{*}}$, and R A Lestari ${ }^{1}$ \\ ${ }^{1}$ Department of Chemical Engineering, Faculty of Engineering, Lambung Mangkurat University, South Kalimantan, Indonesia \\ ${ }^{2}$ Wetland Based Materials Research Group, Lambung Mangkurat $\neg$ University, South Kalimantan, Indonesia
}

\begin{abstract}
Sasirangan - the traditional fabric, claimed as an icon of Banjarmasin and core part of South Kalimantan identity - has been produced for a long time by home industries and contributes to local community economic development. Practically, activities of Sasirangan home industries use several chemical coloring agents that produce liquid waste and harm the ecological life of the Martapura River in Banjarmasin. The purpose of this study is to identify the potential of liquid waste of sasirangan for pollution in the Martapura River. Certainly, It would importantly contribute to providing a solution to overcome these waste effects on the surrounding environment. This study used the observation method and survey approach to the Sasirangan home industry in three locations around the Martapura River in Banjarmasin City. Sampling was conducted both at the point of the inlet and outlet of these locations. Then, the samples were laboratory tested and quantitatively analyzed for biological parameters (total $\mathrm{Cr}$ and total Cd content in Snakehead Fish) and chemical parameters (BOD, COD, and content of oil and fat). The results showed that the wastewater content of sasirangan generally was still within the limits of quality standards permitted according to the Governor of South Kalimantan Regulation Number 04 the Year 2007. Nevertheless, there were still several parameters that exceed the quality standard, for the content of heavy metal chromium in Snakehead Fish with a value of $0.456 \mathrm{mg} / \mathrm{kg}$ and COD parameters of the upstream sample inlet with a value of 348.9 $\mathrm{mg} / \mathrm{L}$.
\end{abstract}

\section{Introduction}

The development of the industrial sector in Indonesia is currently quite rapid. This is indicated by the increasing number of industries that produce various types of human needs. One of the fastest-growing in the textile industry. South Kalimantan is the producer of the Sasirangan industry. Sasirangan is the traditional fabrics of the Banjar tribe from South Kalimantan Province. Sasirangan fabric is still being produced by the Banjar Community on a home industry scale.

Sasirangan industrial activities in the city of Banjarmasin in practice use several chemicals whose waste impacts the ecological life of rivers in Banjarmasin. Sasirangan industry can be considered as the main source of liquid waste. This is due to the textile refinement process that always uses water as the main auxiliary material in each stage of the process. Water pollution from the sasirangan industry comes from the water discharges and chemical wastes from the production process, waste oil and oil residues, pieces of cloth waste, and others.

Identification of process in sasirangan home industry activities in this study is the first step to be known to investigate the potential of wastewater generated and its effects on the ecological conditions of the Martapura River. This research will certainly contribute positively to providing problem-solving for liquid waste generated by the sasirangan home industry in Banjarmasin.

\section{Materials and Method}

\subsection{Materials}

The materials needed in this study were sasirangan wastewater obtained from sasirangan home industries in Banjarmasin, nitric acid $\left(\mathrm{HNO}_{3}\right)$, and distilled water.

\subsection{Method}

This study used a survey approach and laboratory tests that were analyzed quantitatively.

\subsubsection{Identify the process of the sasirangan home industry.}

Data were collected through the questionnaire survey method to Sasirangan home industries in three locations: Sungai Jingah, Surgi Mufti, and Seberang Masjid, which have a direct impact on the pollution of Martapura River, Banjarmasin. The indicators/parameters were:

- type of coloring agent

- production process

- waste disposal method

\subsubsection{Identification by measurement and analysis of the potential of sasirangan wastewater}

The quality standard parameters of the sasirangan textile industry wastewater are following the Governor of South Kalimantan Regulation No. 4 of 2007 concerning the 
standard quality of the textile industry liquid waste. The indicators/parameters were:

- biological indicator/parameters consisting of laboratory tests for chromium $(\mathrm{Cr})$ and cadmium (Cd) levels contained in snakehead fish

- chemical indicators /parameters consisting of laboratory tests for BOD, COD, oil and fat levels

\section{Result and Discussion}

Sasirangan fabric industry in its manufacture as many other textile industries involves the process of dying. Synthetic dyes such as naphthol, indigo sol, reactive, and indanthreen are used which will produce large amounts of concentrated liquid waste [2]. The use of dyes in the sasirangan home industry in Banjarmasin City is presented in Table 1.

Table 1. Types of Chemicals and Fabric Dyes Used by Sasirangan Home Industry in Banjarmasin

\begin{tabular}{|c|c|c|}
\hline No. & Description & Type \\
\hline \multirow[t]{3}{*}{1} & Chemicals & $\mathrm{Na}_{2} \mathrm{SO}_{4}$ \\
\hline & & SLS \\
\hline & & $\mathrm{NaOH}$ \\
\hline \multirow[t]{10}{*}{2} & Indhanthrene dyes & yellow FG \\
\hline & (hot water only) & gold yellow \\
\hline & & brown \\
\hline & & gray \\
\hline & & violet $2 r / 4 r$ \\
\hline & & black \\
\hline & & red \\
\hline & & green $\mathrm{B}$ \\
\hline & & rsn \\
\hline & & blue $\mathrm{kr}$ \\
\hline \multirow[t]{16}{*}{3} & naphthol dyes & naphthol AS G \\
\hline & (cold water only) & naphthol AS LB \\
\hline & & naphthol AS \\
\hline & & naphthol ASD \\
\hline & & naphthol AS BS \\
\hline & & naphthol AS BO \\
\hline & & naphthol AS BR \\
\hline & & yellow \\
\hline & & orange GC \\
\hline & & red GG \\
\hline & & red $B$ \\
\hline & & violet $B$ \\
\hline & & blue B \\
\hline & & blue $\mathrm{BB}$ \\
\hline & & black B \\
\hline & & tro \\
\hline \multirow[t]{3}{*}{4} & frozen/frosion dyes & red-orange \\
\hline & & red $8 \mathrm{~B}$ \\
\hline & & turkeys \\
\hline
\end{tabular}

The disposal of sasirangan home industry wastes is done carelessly both in the dyeing or washing process that the waste is dumped directly into the nearest land or river. Most of the craftsmen have not made efforts to treat the waste from the production process of sasirangan [6]. Figure 1 shows the liquid waste that is discharged directly to the environment.

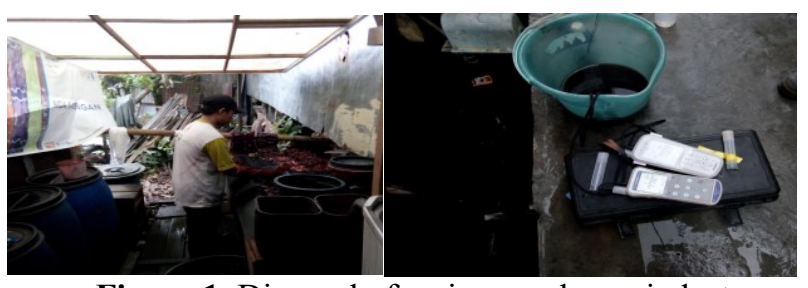

Figure 1. Disposal of sasirangan home industry liquid waste.

Identification of sasirangan home industry wastewater in Banjarmasin was done by measuring six samples: 3 samples (inlet) at the processing location of the Sasirangan home industry and 3 samples (outlets) at the Martapura River area. The parameters measured include 2 indicators namely biology and chemistry that were adjusted to the Governor Regulation of South Kalimantan Province Number 04 of 2007 Attachment 1.10 concerning Quality Standards for Textile Industry Liquid Waste.

The biological indicators measured in this study were the heavy metal element $\mathrm{Cd}$ (cadmium) and $\mathrm{Cr}$ (total chromium) in $\mathrm{mg} /$ fish units. The type of fish chosen is Snakehead Fish as one of the typical fish species that live in the Martapura River and is consumed by people in the city of Banjarmasin. The result of the test is shown inTable 2.

Table 2. The content of metal element $\mathrm{mg} / \mathrm{kg}$ in Snakehead fish in the Martapura River.

\begin{tabular}{lcccc}
\hline \multicolumn{1}{c}{$\begin{array}{c}\text { The } \\
\begin{array}{c}\text { content of } \\
\text { the metal } \\
\text { element }\end{array}\end{array}$} & Unit & $\begin{array}{c}\text { Max. } \\
\text { Level }\end{array}$ & Result & Method \\
\hline $\begin{array}{l}\text { (Cr) } \\
\begin{array}{l}\text { Chrom } \\
\text { total } \\
\text { (Cd) } \\
\text { Cadmium }\end{array}\end{array}$ & $\mathrm{mg} / \mathrm{kg}$ & 0.1 & 0.456 & $\begin{array}{l}\text { APHA 3120 B } \\
\text { 22 2012 (ICP) }\end{array}$ \\
\hline
\end{tabular}

Cadmium is a heavy metal with high toxicity that it is dangerous for living things, especially if consumed by humans. Cadmium can be contained through waste streams that enter and contaminate the river so that animal and plant ecosystems are affected by these heavy metals.

Chromium metal elements can enter the body of water in two ways: natural and non-natural. The entry of chromium naturally can be caused by several physical factors, such as erosion that occurs in mineral rocks. The entry of chromium that occurs non-naturally is more an impact or effect of human activities

Based on biological parameters described in Table 2 , it is known that the content of cadmium heavy metal elements in the species of Snakehead fish in the Martapura River which is equal to $0.033 \mathrm{mg} / \mathrm{kg}$ is still within the safe threshold of maximum consumption of $0.1 \mathrm{mg} / \mathrm{kg}$ based on The Regulation of Head of Indonesia National Agency of Drug and Food Control No. HK.00.06.1.52.4011 concerning Determination of Maximum Limits of Microbial and Chemical Contamination in Foods. While total chromium $(\mathrm{Cr})$ 
Table 3. Biochemical Oxygen Demand (BOD) (mg/L).

\begin{tabular}{clccrl}
\hline No & \multicolumn{1}{c}{ Location } & $\begin{array}{c}\text { Max. } \\
\text { Level }\end{array}$ & $\begin{array}{c}\text { Result } \\
\text { (inlet) }\end{array}$ & $\begin{array}{c}\text { Result } \\
\text { (Outlet) }\end{array}$ & Method \\
\hline 1 & Rose sasirangan (Hilir) & 50 & 10.12 & 9.12 & IKM/5.4.1023/LABKE \\
2 & Nida Sasirangan (Tengah) & 50 & 59.12 & 8.15 & IKM/5.4.1023/LABKE \\
3 & Tati sasirangan (Hulu) & 50 & 10.17 & 11.74 & IKM/5.4.1023/LABKE \\
\hline
\end{tabular}

Table 4. Chemical Oxygen Demand (COD) (mg/L).

\begin{tabular}{clcrrr}
\hline No & \multicolumn{1}{c}{ Location } & $\begin{array}{c}\text { Max. } \\
\text { Level }\end{array}$ & $\begin{array}{c}\text { Result } \\
\text { (inlet) }\end{array}$ & $\begin{array}{c}\text { Result } \\
\text { (Outlet) }\end{array}$ & Method \\
\hline 1 & Rose sasirangan (Hilir) & 100 & 25.89 & 25.62 & SNI 6989.2:2009 \\
2 & Nida Sasirangan (Tengah) & 100 & 1.455 & 20.84 & SNI 6989.2:2009 \\
3 & Tati sasirangan (Hulu) & 100 & 348.9 & 24.99 & SNI 6989.2:2009 \\
\hline
\end{tabular}

Table 5. Oil and Fat Parameters (mg/L).

\begin{tabular}{cccccc}
\hline No & Location & Max. Level & $\begin{array}{c}\text { Result } \\
\text { (inlet) }\end{array}$ & $\begin{array}{c}\text { Result } \\
\text { (Outlet) }\end{array}$ & Method \\
\hline 1 & $\begin{array}{c}\text { Tati sasirangan } \\
\text { (Hulu) }\end{array}$ & 10 & 0,4 & $<0.005$ & SNI 06-6989.10.2004 \\
2 & $\begin{array}{c}\text { Nida Sasirangan } \\
\text { (Tengah) }\end{array}$ & 10 & 2 & $<0.005$ & SNI 06-6989.10.2004 \\
3 & $\begin{array}{c}\text { Rose sasirangan } \\
\text { (Hilir) }\end{array}$ & 10 & 0,2 & $<0.005$ & SNI 06-6989.10.2004 \\
\hline
\end{tabular}

levels of $0.456 \mathrm{mg} / \mathrm{kg}$ still exceed the safe threshold of consumption. This certainly needs further attention.

Table 3 shows that the BOD parameters of 6 locations (3 inlet locations and 3 outlet locations) were generally below the threshold of $50 \mathrm{mg} / \mathrm{L}$ based on South Kalimantan Province Governor Regulation No. 4 of 2007 concerning Textile Industry Liquid Waste Water Quality Standards. But there was still result from one inlet sample with a value slightly above the threshold, which is $59.12 \mathrm{mg} / \mathrm{L}$ BOD is used as a measure of the amount of oxygen used by microbial populations contained in waters in response to the entry of biodegradable organic matter or as a description of the number of biodegradable organics in the waters [9].

The next chemical parameter observed was Chemical Oxygen Demand (COD). COD is the amount of oxygen needed to decompose all organic matter contained in water. COD values in the research area are presented in Table 4.

COD or chemical oxygen demand is the amount of oxygen needed so that organic wastes in the water can be oxidized through chemical reactions. COD value is a measure of the level of pollution by organic matter [9]. Table 4 shows that the COD parameters of 6 locations ( 3 inlet locations and 3 outlet locations), 5 locations were below the threshold according to South Kalimantan Province Governor Regulation No. 4 of 2007 concerning Textile Industry Liquid Wastewater Quality Standards which is $100 \mathrm{mg} / \mathrm{L}$ and one sample was above the threshold with a COD value of $348.9 \mathrm{mg} / \mathrm{L}$.

The next parameter to identify the potential of sasirangan dyes liquid waste is oil and fat content. Oil and fat are parameters whose maximum concentrations are required for industrial wastewater and surface water. Oil has a specific gravity smaller than water so it will form a thin layer on the surface of the water. This condition can reduce the concentration of dissolved oxygen in the water because free oxygen fixation is inhibited. The oil that covers the surface of the water will also inhibit the penetration of sunlight into the water so that it disrupts the imbalance of the food chain. The oil and fat content in the study location is presented in Table 5.

Table 5 explains that the oil and fat parameters from 6 locations ( 3 inlet locations and 3 outlet locations) were below the threshold according to South Kalimantan Province Governor Regulation No. 4 of 2007 concerning the Textile Industry Liquid Wastewater Quality Standards.

\section{Conclusion}

The home industry of Sasirangan in Banjarmasin majority uses chemical dyes. The types of chemicals used include Indhanthrene Color (for hot water), Naphthol Color (for cold water), and Frozen/Frosion Color.

Analysis of the potential impact of Sasirangan wastewater at the processing site of the Sasirangan home industry and the Martapura River for biological, physical, and chemical indicators, in general, were still below the threshold permitted following South Kalimantan Provincial Governor Regulation Number 04 of 2007. However, there were still results of analyzes that exceed the quality limits of that regulation, namely:

- Biological parameter: total chromium (Cr) levels contained in snakehead fish with a value of 0.456 $\mathrm{mg} / \mathrm{kg}$ exceeding the safe threshold of consumption $0.1 \mathrm{mg} / \mathrm{kg}$

- Chemical parameter: COD (one inlet sample) with a COD value of $348.9 \mathrm{mg} / \mathrm{L}$ exceeding the maximum threshold of $100 \mathrm{mg} / \mathrm{L}$

Corresponding author: desi.nurandini@ulm.ac.id 
We would like to thanks the Engineering Faculty, the University of Lambung Mangkurat which provided The Research Grant.

\section{References}

1. O. Akhyar, A. Pardede, W. Kusuma, and R.R.A. Alicia Science Media 9(2),

2. R. Hardini, I. Risnawati, A. Fauzi \& N. Komari Journal of Sains and Applied Chemistry, 3 (1): 5772, (2009)

3. U. Irawati, U.B.L. Utami, and H. Muslima. Journal of Sains and Applied Chemistry, 5(1): 34-44, (2011)

4. Metcalf and Eddy 1993 Wastewater Engineering Treatment Disposal Reuse McGraw-Hill Comp.

5. S. Mawaddah. Analisis Krom (Cr) Dalam Limbah Industri Kain Sasirangan Skripsi, (2002)

6. A. Mizwar, Diena, N.F. Nurin. Info Teknik, 13(1), (2012)

7. N.S. Mratihatani and I. Susilowati. DIPONEGORO Journal of Economics, 2, 1-12, (2013)

8. Governor Regulation of South Kalimantan Province Number 04. Quality Standards for Textile Industry Liquid Waste, (2007)

9. Y. Pratiwi. Journal of Technology, 3(2): 129-137, (2010)

10. E. Septiyani, T. Istirokhatun, and H. Susanto. Journal of Environmental Engineering, 6 (1), (2017)

11. U.B.L. Utami and R. Nurmasari. Journal of Science MIPA. 13 (3): 190-196, (2007) 